\title{
Ataxia-Telangiectasia-Like Disorder 1
}

National Cancer Institute

\section{Source}

National Cancer Institute. Ataxia-Telangiectasia-Like Disorder 1. NCI Thesaurus. Code C132224.

An autosomal recessive condition caused by mutation(s) in the MRE11A gene, encoding double-strand break repair protein MRE11. It is characterized by progressive cerebellar degeneration resulting in ataxia and oculomotor apraxia. 